\title{
Immunoreactive Calcitonin Cells in the Nervous System of Polychaete Perinereis aibuhitensis
}

Kase, Yoichi

Noto Marine Laboratory, Institute of Nature and Environmental Technology, Division of Marine Environmental Studies, Kanazawa University | Laboratory of Marine Environmental Science, Faculty of Agriculture, Kyushu University

Ogiso, Shouzo

Noto Marine Laboratory, Institute of Nature and Environmental Technology, Division of Marine Environmental Studies, Kanazawa University | Laboratory of Marine Environmental Science, Faculty of Agriculture, Kyushu University

Ikari, Takahiro

Noto Marine Laboratory, Institute of Nature and Environmental Technology, Division of Marine Environmental Studies, Kanazawa University | Laboratory of Marine Environmental Science, Faculty of Agriculture, Kyushu University

Sekiguchi, Toshio

Noto Marine Laboratory, Institute of Nature and Environmental Technology, Division of Marine Environmental Studies, Kanazawa University | Laboratory of Marine Environmental Science, Faculty of Agriculture, Kyushu University

他

https://doi.org/10.5109/1854010

出版情報：九州大学大学院農学研究院紀要. 62 (2)，pp.381-385，2017-09-08. Faculty of Agriculture, Kyushu University

バージョン :

権利関係 : 


\title{
Immunoreactive Calcitonin Cells in the Nervous System of Polychaete Perinereis aibuhitensis
}

\author{
Yoichi KASE ${ }^{1}$, Shouzo OGISO ${ }^{1}$, Takahiro IKARI ${ }^{1}$, Toshio SEKIGUCHI ${ }^{1}$, Yuichi SASAYAMA ${ }^{1}$, \\ Yoichiro KITANI ${ }^{1}$, Yohei SHIMASAKI, Yuji OSHIMA, Akira KAMBEGAWA ${ }^{2}$, \\ Yoshiaki TABUCHI ${ }^{3}$, Atsuhiko HATTORI ${ }^{4}$ and Nobuo SUZUKI ${ }^{1 *}$
}

\author{
Laboratory of Marine Environmental Science, Faculty of Agriculture, Kyushu University, \\ Hakozaki 6-10-1, Higashi-ku, Fukuoka, 812-8581, Japan \\ (Received April 28, 2017 and accepted May 10, 2017)
}

\begin{abstract}
We examined immunoreactive calcitonin (iCT) cells in the nervous system of the polychaete Perinereis aibuhitensis using immunohistochemical methods. We found the most iCT cells (53-70 cells) in the cerebral ganglion. We also detected iCT cells (4-6 cells) in the subpharyngeal ganglion. Furthermore, it was noted that iCT cells were present bilaterally in each segment of the ventral nerve cord. These results suggest that iCT cells play some functional roles in the nervous system. Next, the molecular weight (MW) of the iCT substance was examined using the western blotting method. Cerebral ganglia were collected from 200 individuals. These ganglia were homogenized and centrifuged. The separated supernatants were treated with $66 \%$ acetone and then dialyzed to remove low MW substances (less than 2,000 ) at $4^{\circ} \mathrm{C}$. After lyophilization, the sample was reconstituted with $1 \mathrm{M}$ acetic acid and then fractionated with an ultrafiltration membrane system into MWs of 3,000 to 10,000. Thereafter, the specimen was separated by SDS-polyacrylamide gel electrophoresis and analyzed by western blotting with anti-salmon calcitonin (CT) antiserum. Our results indicated that the MW of the iCT substance was close to that of teleost fish CT (3.5 kDa). The annelid Capitella teleta has two genes encoding CT-like peptides. This suggests that the iCT substance in $P$. aibuhitensis includes amino acid residues similar to fish CT and belongs to the CT family.
\end{abstract}

Key words: immunoreactive calcitonin cells, polychaete, central nervous system, western blotting

\section{INTRODUCTION}

Calcitonin (CT) is a peptide hormone composed of 32 amino acids with two N-terminal cysteine residues. This hormone is secreted from C-cells of thyroid glands in mammals or from parenchymal cells of ultimobranchial glands in non-mammalian vertebrates (see a review, Sasayama, 1999). CT has a hypocalcemic function resulting from the suppression of osteoclasts in mammals (see a review, Wimalawansa, 1997). Also, CT suppressed osteoclastic activity in goldfish (freshwater teleosts) and nibbler fish (marine teleosts) (Suzuki et al., 2000a). In addition, CT plays a role in the excretion of extra calcium after calcium is injected in eels (Suzuki et al., 1999) and stonefish (Kaida and Sasayama, 2003).

On the other hand, CT is present in various tissues such as the gut, gonads, lungs, and brain in vertebrates (Azria, 1989). Immunoreactive calcitonin (iCT) was also detected in the central nervous systems of several verte-

Noto Marine Laboratory, Institute of Nature and Environmental Technology, Division of Marine Environmental Studies, Kanazawa University, Housu-gun, Ishikawa 927-0553, Japan

Kambegawa Laboratory, Tokyo 201-0013, Japan

Division of Molecular Genetics Research, Life Science Research Center, University of Toyama, Sugitani, Toyama 9300194, Japan

${ }^{4}$ Department of Biology, College of Liberal Arts and Sciences, Tokyo Medical and Dental University, Ichikawa, Chiba 2720827, Japan

* Corresponding author (E-mail: nobuos@staff.kanazawa-u. ac.jp) brate classes (humans: Fischer et al., 1983; rats: Flynn et al., 1981; pigeons: Galan Galan et al., 1981a; lizards: Galan Galan et al., 1981b; bullfrogs: Yui, 1983; lampreys and hagfish: Sasayama et al., 1991). Furthermore, CT receptors have been detected in the brain of flounders (Suzuki et al., 2000b), stingrays (Suzuki et al., 2012), rats (Becskei et al., 2004), and humans (Bower et al., 2016), indicating that CT has some neurophysiological functions in addition to calcium regulation. In mammals, CT actually has an analgesic effect, probably caused by increases in plasma $\beta$-endorphin levels and interaction with the endogenous opiate system (see a review, Hamdy and Daley, 2012).

In a species of protochordate (Ciona intestinalis), CT has been determined (Sekiguchi et al., 2009). This protochordate CT was composed of 30 amino acids with two N-terminal cysteine residues and acted to suppress osteoclasts in goldfish (Sekiguchi et al., 2009). Furthermore, this molecule is expressed in the neural complex of juveniles (Sekiguchi et al., 2009). Taking these facts into consideration, CT also plays some roles in the nervous systems of invertebrates.

We focused on one species of polychaeata Perinereis aibuhitensis. This worm is easy to collect because this species is imported from Korea for fishing bait. Therefore, we examined CT-producing cells by immunohistochemical methods. Furthermore, to analyze the biochemical characterization of the iCT substance, its molecular weight (MW) was investigated by western blotting with anti-salmon CT antiserum. 


\section{MATERIALS AND METHODS}

\section{Animals}

Polychaetes were purchased from a fishing shop. For acclimation, the worms were kept in an aquarium for three days with aeration.

\section{Detection of iCT cells}

The bodies of worms $(n=10)$ were separated into 12 portions. One portion consisted of nine segments. These portions were fixed with Bouin solution without acetic acid (Okuda et al., 1999) and then were preserved in 70\% ethyl alcohol. Tissues embedded in paraffin were serially sectioned at $10 \mu \mathrm{m}$ by a routine paraffin method. The paraffin sections were incubated with an anti-salmon CT polyclonal antibody (1/100,000 dilution). This antiserum was prepared in the rabbit by the injection of synthetic salmon CT (Teikokuzouki Co. Ltd., Tokyo, Japan) which had been combined with bovine serum albumin. The specificity of this antiserum has been analyzed by enzyme-linked immunosorbent assay (Suzuki, 2001). Then, the paraffin sections were incubated with biotinylated anti-rabbit immunoglobulins goat antibody (1/2,000 dilution) (E 432, Dako Japan Co. Ltd., Kyoto, Japan). Thereafter, iCT cells were detected using a labeled streptavidin-biotin kit (Dako Japan Co. Ltd.). All steps were incubated on a horizontal shaker.

\section{Determination of iCT substance}

The cerebral ganglia were dissected out under a binocular microscope. The tissues were immediately frozen and kept at $-80^{\circ} \mathrm{C}$ until use. The procedures for preparing the crude extracts and fractionating them are indicated in Figure 1. To prepare the crude extract, the ganglia were boiled for $10 \mathrm{~min}$ with $5 \mathrm{ml}$ of distilled water to deactivate the endogenous proteases. The resultant suspension was immediately cooled and acidified with glacial acetic acid to make a final concentration of $1 \mathrm{M}$. Then, the acid-treated samples were homogenized at $4^{\circ} \mathrm{C}$ with a glass homogenizer and centrifuged at 25,000 $\times \mathrm{g}$ for $10 \mathrm{~min}$ at $4^{\circ} \mathrm{C}$.

The crude extract was treated with $66 \%$ acetone to remove high molecular proteins. After centrifugation, the supernatant was dialyzed (Spectra/Por, MWCO 2000, Spectrum Laboratories, Inc., Rancho Dominguez, CA, USA) to remove low MW substances (less than 2,000) at $4^{\circ} \mathrm{C}$. After lyophilization, the sample was reconstituted with $1 \mathrm{M}$ acetic acid and then fractionated with ultrafiltration membrane systems into MWs of 3,000 to 10,000 (Centricon, Merck Millipore Corporation, Darmstadt, Germany). Namely, the sample was filtered with a MW of 10,000 (Centricon, Merck Millipore Corporation), and the filtrated sample was then subjected to a MW of 3,000 (Centricon, Merck Millipore Corporation).

The fractionated samples (MWs of 3,000 to 10,000) were lyophilized and then solubilized in lysis buffer containing 4\% sodium dodecyl sulfate, 4\% 2-mercaptoethanol, $8 \mathrm{M}$ urea, and $10 \mathrm{mM}$ Tris- $\mathrm{HCl}(\mathrm{pH} \mathrm{6.8)}$ and subjected to electrophoresis. Eel CT (Wako Pure Chemical Industries, Ltd., Osaka, Japan) was used as a positive

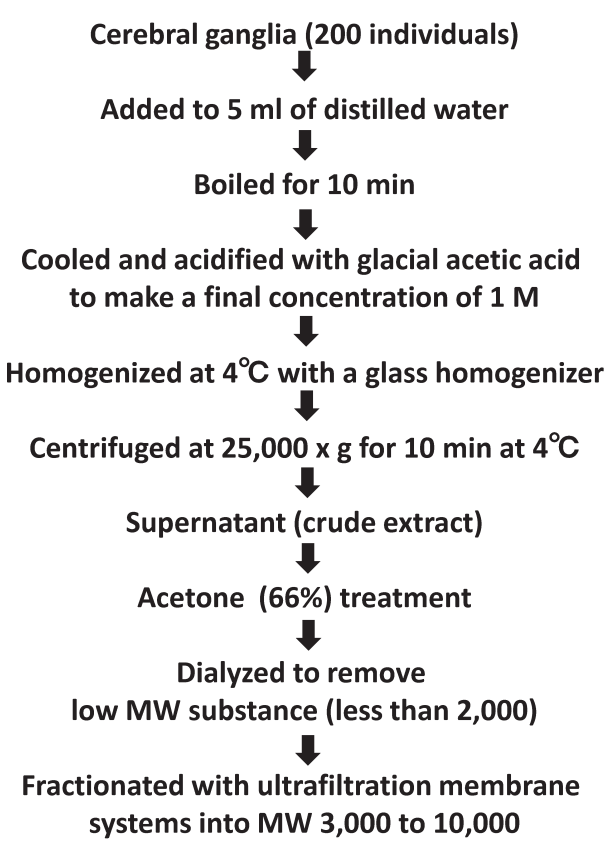

Fig. 1. The procedure of preparing and fractionating of crude extracts from cerebral ganglia in a polychaete $P$. aibuhitensis.

The cerebral ganglia were collected from 200 individuals. These ganglia were homogenized and centrifuged. The separated supernatants were treated with $66 \%$ acetone and then dialysis to remove low molecular weight (MW) substances (less than 2,000). Thereafter, the sample was fractionated with an ultrafiltration membrane system into MWs of 3,000 to 10,000 .

control. The separation gel was prepared with a linear gradient from $10 \%$ to $20 \%$ polyacrylamide. Samples separated by electrophoresis were transferred to a polyvinylidene difluoride membrane (Clear Blot Membrane-P; Atto Co. Ltd., Tokyo, Japan) at room temperature for $2.5 \mathrm{~h}$ at $16 \mathrm{~V} / \mathrm{cm}$ (Suzuki et al., 1995). Thereafter, the membrane was washed three times in a $10 \mathrm{mM}$ phosphate buffer solution containing 0.05\% Tween 20 (PBST) adjusted with $\mathrm{HCl}$ to $\mathrm{pH} 7.2$. Then, PBST containing $1 \%$ normal swine serum was used to block the non-specific binding of the antibody onto the membrane for $30 \mathrm{~min}$ at room temperature. After washing with PBST, the membrane was then treated with salmon CT antiserum for 12-15 hours at room temperature. The unbound antiserum was removed by washing with PBST. Then, the membrane was incubated with biotinylated anti-rabbit immunoglobulin goat antibody (E 432, Dako Japan Co. Ltd.). After washing with PBST, the target protein was detected using a labeled streptavidin-biotin kit (Dako Japan Co. Ltd.) to immunostain the membrane.

\section{RESULTS}

\section{Detection of iCT cells by immunohistochemical methods}

The distribution of iCT cells is summarized in Figure 2. The most iCT cells (53-70 cells) were in the cerebral ganglion (Figs. 3A and 3B), the portion including head. 


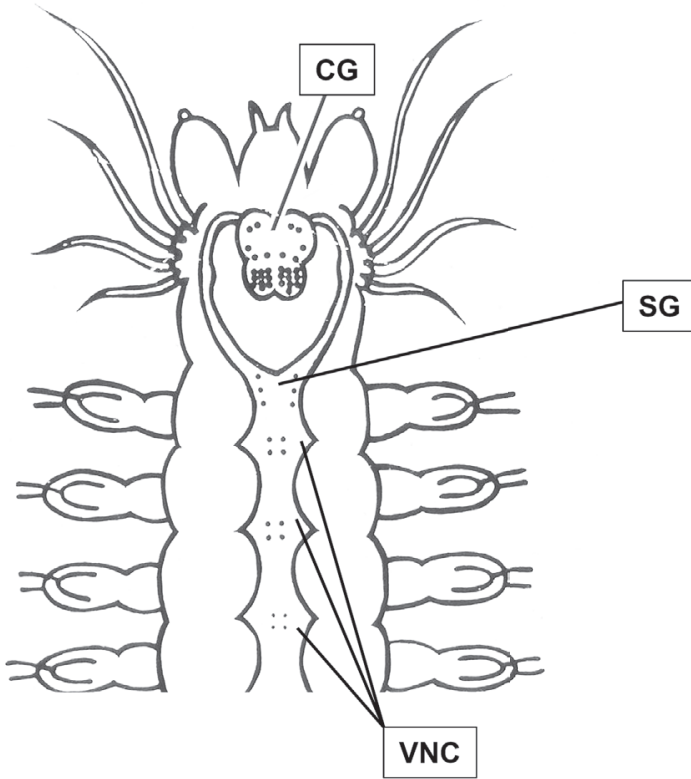

Fig. 2. Schematic drawings showing the distribution and number of immunoreactive calcitonin cells (black spots) in a polychaete $P$. aibuhitensis

The size of the black spots is shown according to the strength of the positive reaction. CG: cerebral ganglion; SG: subpharyngeal ganglion; VNC: ventral nerve cord.

In other parts, iCTs were detected in the subpharyngeal ganglion (4-6 cells). Furthermore, 4 iCT cells were found in each segment of the ventral nerve cord (Fig. 3C). These iCT cells were detected in two pairs-right and left sides—at each segment (Fig. 2).

\section{Analysis of the $\mathrm{iCT}$ substance in polychaetes}

The results of western blotting of the cerebral ganglia (200 individuals) are indicated in Figure 4. We found that the MW of the iCT substance in this polychaete was close to that of teleost fish CT (3.5 kDa) (Fig. 4).

\section{DISCUSSION}

iCT cells were detected not only in cerebral ganglia, but also in subpharyngeal ganglia and ventral nerve cord of the polychaete P. aibuhitensis (Figs. 2 and 3). It is known that in a gastropod Physella heterostropha, syn-

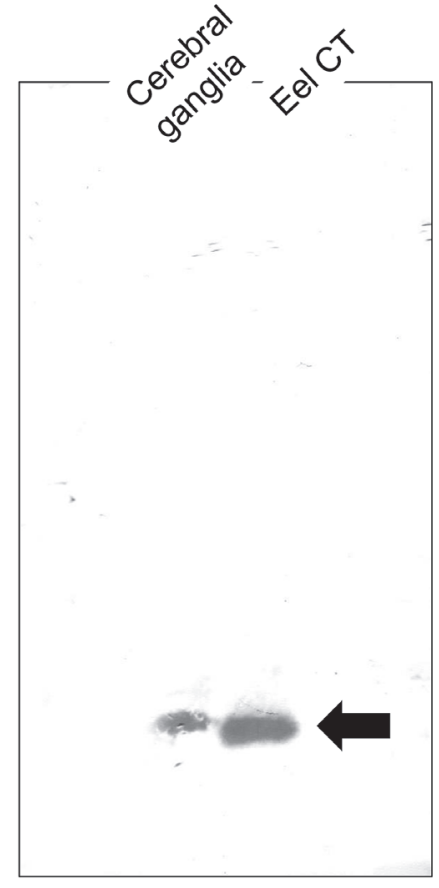

Fig. 4. Analysis of immunoreactive calcitonin (iCT) substance by western blotting.

Molecular weight of the iCT substance in the polychaete $P$. aibuhitensis was close to that of eel calcitonin (CT) (3.5 kDa) (Arrow).

thetic somatostatin and salmon CT promoted neurite formation in a dose-dependent manner, although other hormones, such as thyrotropin-releasing hormones, arginine vasotocin, and eledoisin, failed to promote neurite outgrowth (Grimm-Jørgensen, 1987). In another species of gastropod Aplysia kurodai, the effect of salmon CT on the neurons (R9 and R10) of abdominal ganglia has also been reported (Sawada et al., 1993). This examination using A. kurodai indicated that micropressure-ejected salmon CT induced a slow outward current associated with a decrease in $\mathrm{Na}^{+}$conductance, causing membrane hyperpolarization (Sawada et al., 1993). In A. kurodai, therefore, CT may act as an inhibitory neurotransmitter that regulates the firing pattern of major neurons in abdominal ganglia. In the present study, it is remarkable that iCT cells were also present in the subpharyngeal nerve and ventral nerve cord in addition to
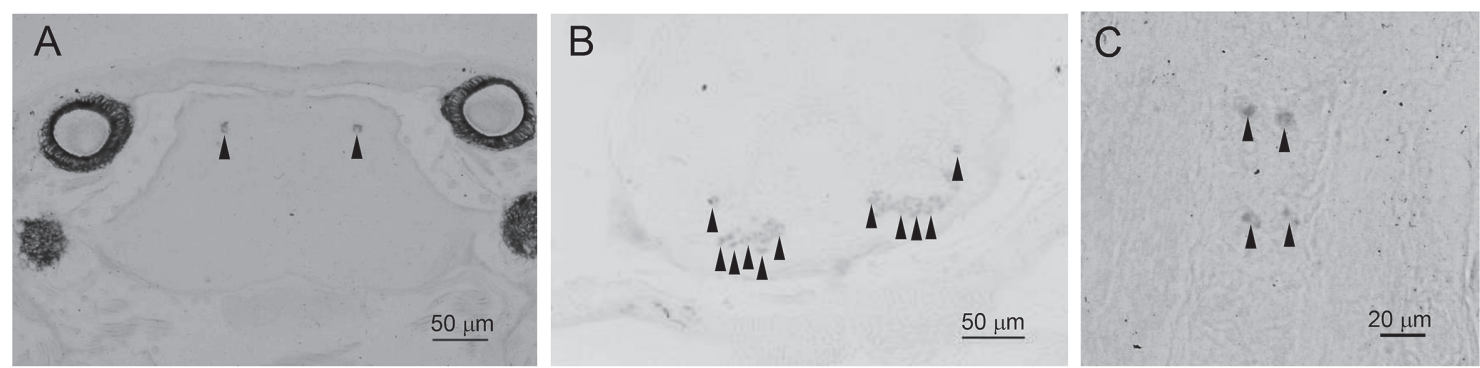

Fig. 3. Immunoreactive calcitonin (iCT) cells in a polychaete $P$. aibuhitensis.

A: cerebral ganglion (anterior region); B: cerebral ganglion (posterior region); C: ventral nerve cord. Arrowheads indicate iCT cells. 
the central ganglion. Moreover, we found out that those cells looked to be in a row systematically in each body segment (Fig. 2). This arrangement of iCT cells has some physiological meaning in this worm.

In A. kurodai, Sawada et al. (1993) reported that extra-cellular micropressure ejection of forskolin (an activator of cyclic adenosine 3,5'-monophosphate) induced hyperpolarization in the $\mathrm{R} 9$ neuron of abdominal ganglia. This phenomenon seems to be mediated by a receptor that regulates increase of intracellular cyclic adenosine 3',5'-monophosphate. In the polychaete $P$. aibuhitensis, therefore, the iCT substance may function as a neurohormone via CT receptor because CT increases intracellular cyclic adenosine 3',5'-monophosphate after binding CT receptor (see a review, Goldring et al., 1993). The CT family receptor has been sequenced in invertebrates such as the bivalve mollusc (Crassostrea gigas: Dubos et al., 2003) and chordates (C. intestinalis: Sekiguchi et al., 2009; Branchiostoma floridae: Sekiguchi et al., 2016). The CTs of both $C$. intestinalis and B. floridae are bioactive in fish osteoclasts (Sekiguchi et al., 2009; Sekiguchi et al., 2017). In the annelid Capitella teleta, two genes encode CT-like peptides, one encodes a CT-type peptide (31 amino acid residues) with two $\mathrm{N}$-terminal cysteine residues, and one encodes a diuretic hormone 31-type peptide without two N-terminal cysteine residues (Rowe et al., 2014). We found that the MW of the iCT substance in this polychaete was close to that of teleost fish CT (3.5 kDa) (Fig. 4). Thus, the iCT substance in $P$. aibuhitensis may include amino acid residues similar to fish CT and may belong to the CT family.

\section{AUTHOR CONTRIBUTIONS}

Y. Kase, Y. Sasayama, A. Kambegawa and N. Suzuki designed the study. Y. Kase and N. Suzuki performed the histological experiments and western blotting. S. Ogiso, Y. Kitani, T. Ikari, T. Sekiguchi, Y. Tabuchi, and A. Hattori analyzed the data and wrote the paper. Y. Oshima and Y. Shimasaki supervised the work. All authors assisted in editing of the manuscript and approved the final version.

\section{ACKNOWLEDGMENTS}

This study was supported in part by grants to N.S. (Grant-in-Aid for Scientific Research [C] No. 16K07871 by JSPS), to S.O. (Grant-in-Aid for Encouragement of Scientists No. $16 \mathrm{H} 00450$ by JSPS), and to T.S. (Scientific Research [C] No. 15K07126 by JSPS). This work was partly supported by the cooperative research program of the Institute of Nature and Environmental Technology, Kanazawa University, Acceptance No. 11 in 2016.

\section{REFERENCES}

Azria, M 1989 The Calcitonins: Physiology and Pharmacology. Karger, Basel.

Becskei, C., T. Riediger, D. Zünd, P. Wookey and T. A. Lutz 2004 Immunohistochemical mapping of calcitonin receptors in the adult rat brain. Brain Res., 1030: 221-233

Bower, R. L., S. Eftekhari, H. J. Waldvogel, R. L. Faull, J. Tajti, L. Edvinsson, D. L. Hay and C. S. Walker 2016 Mapping the calcitonin receptor in human brain stem. Am. J. Physiol. Regul. Integr. Comp. Physiol., 310: R788-R793

Dubos, M. P., F. Badariotti, F. Rodet, C. Lelong and P. Favrel 2003 Molecular and physiological characterization of an invertebrate homologue of a calcitonin-related receptor. Biochem. Biophys. Res. Commun., 310: 972-978

Fischer, J. A., P. H. Tobler, H. Henke and F. A. Tschopp 1983 Salmon and human calcitonin-like peptides coexist in the human thyroid and brain. J. Clin. Endocrinol. Metab., 57: 1314-1316

Flynn, J. J., D. L. Margules and C. W. Cooper 1981 Presence of immunoreactive calcitonin in the hypothalamus and pituitary lobes of rats. Brain Res. Bull., 6: 547-549

Galan Galan. F., R. M. Rogers, S. I. Girgis and I. MacIntyre 1981a Immunoreactive calcitonin in the central nervous system of the pigeon. Brain Res., 212: 59-66

Galan Galan, F., R. M. Rogers, S. I. Girgis, T. R. Arnett, M. Ravazzola, L. Orci and I. MacIntyre 1981b Immunochemical characterization and distribution of calcitonin in the lizard. Acta Endocrinol., 97: 427-432

Goldring, S. R., A. H. Gorn, M. Yamin, S. M. Krane and J. T. Wang 1993 Characterization of the structural and functional properties of cloned calcitonin receptor cDNAs. Horm. Metab. Res., 25: 477-480

Grimm-Jørgensen, Y 1987 Somatostatin and calcitonin stimulate neurite regeneration of molluscan neurons in vitro. Brain Res., 403: 121-126

Hamdy, R. C. and D. N. Daley 2012 Oral calcitonin. Int. J. Womens Health, 4: 471-479

Kaida, N. and Y. Sasayama 2003 Dynamics of plasma Ca and calcitonin levels in stonefish (Inimicus japonicus) administered a high-Ca solution into the stomach. Zool. Sci., 20: 353-356

Okuda, R., Y. Sasayama, N. Suzuki, A. Kambegawa and A. K. Srivastav 1999 Calcitonin cells in the intestine of goldfish and a comparison of the number of cells among saline-fed, soupfed, or high Ca soup-fed fishes. Gen. Comp. Endocrinol., 113 : 267-273

Rowe, M. L., S. Achhala and M. R. Elphick 2014 Neuropeptides and polypeptide hormones in echinoderms: new insights from analysis of the transcriptome of the sea cucumber Apostichopus japonicus. Gen. Comp. Endocrinol., 197: 43-55

Sasayama, Y., T. Koizumi, C. Oguro, A. Kambegawa and H. Yoshizawa 1991 Calcitonin-immunoreactive cells are present in the brains of some cyclostomes. Gen. Comp. Endocrinol., 84: 284-290

Sasayama, Y 1999 Hormonal control of Ca homeostasis in lower vertebrates: considering the evolution. Zool. Sci., 16: 857-869

Sawada, M., M. Ichinose, S. Ishikawa and Y. Sasayama 1993 Calcitonin induces a decreased $\mathrm{Na}^{+}$conductance in identified neurons of Aplysia. J. Neurosci. Res., 36: 200-208

Sekiguchi, T., N. Suzuki, N. Fujiwara, M. Aoyama, T. Kawada, K. Sugase, Y. Murata, Y. Sasayama, M. Ogasawara and H. Satake 2009 Calcitonin in a protochordate, Ciona intestinalis: the prototype of the vertebrate calcitonin/calcitonin gene related peptide superfamily. FEBS J., 276: 4437-4447

Sekiguchi, T., K. Kuwasako, M. Ogasawara, H. Takahashi, S. Matsubara, T. Osugi, I. Muramatsu, Y. Sasayama, N. Suzuki and H. Satake 2016 Evidence for conservation of the calcitonin superfamily and activity-regulating mechanisms in the basal chordate Branchiostoma floridae: insights into the molecular and functional evolution in chordates. J. Biol. Chem., 291: $2345-2356$

Sekiguchi, T., A. Shiraishi, H. Satake, K. Kuwasako, H. Takahashi, M. Sato, M. Urata, S. Wada, M. Endo, T. Ikari, A. Hattori, A.K. Srivastav and N. Suzuki 2017 Calcitonin-typical suppression of osteoclastic activity by amphioxus calcitonin superfamily peptides and insights into the evolutionary conservation and diversity of their structures. Gen. Comp. Endocrinol., 246: 
294-299

Suzuki, N., Y. Kase, Y. Sasayama, A. Kambegawa, W. Magtoon and A. K. Srivastav 1995 Partial characterization of a calcitoninlike substance from the Brockmann bodies of the medaka Oryzias latipes. Fisheries Sci., 61: 687-690

Suzuki, N., D. Suzuki, Y. Sasayama, A. K. Srivastav, A. Kambegawa and K. Asahina 1999 Plasma calcium and calcitonin levels in eels fed a high calcium solution or transferred to seawater. Gen. Comp. Endocrinol., 114: 324-329

Suzuki, N., T. Suzuki and T. Kurokawa 2000a Suppression of osteoclastic activities by calcitonin in the scales of goldfish (freshwater teleost) and nibbler fish (seawater teleost). Peptides, 21: 115-124

Suzuki, N., T. Suzuki and T. Kurokawa 2000b Cloning of a calcitonin gene-related peptide receptor and a novel calcitonin receptor-like receptor from the gill of flounder, Paralichthys olivaceus. Gene, 244: 81-88
Suzuki, N 2001 Calcitonin-like substance in the plasma of Cyclostomata and its putative role. Comp. Biochem. Physiol. Part B, 129: 319-326

Suzuki, N., T. Sekiguchi H. Satake, K. Kato, Y. Nishiyama, H. Takahashi, J. A. Danks, T. J. Martin, A. Hattori, M. Nakano, M. Kakikawa, S. Yamada, M. Ogoshi, S. Hyodo, Y. Yamaguchi, V. S. Chowdhury, K. Hayakawa, H. Funahashi, T. Sakamoto and Y. Sasayama 2012 Cloning of two members of the calcitoninfamily receptors from stingray, Dasyatis akajei: possible physiological roles of the calcitonin family in osmoregulation. Gene, 499: 326-331

Wimalawansa, S. J. 1997 Amylin, calcitonin gene-related peptide, calcitonin, and adrenomedullin: a peptide superfamily. Crit. Rev. Neurobiol., 11: 167-239

Yui, R 1983 Immunohistochemical studies on peptide neurons in the hypothalamus of the bullfrog Rana catesbeiana. Gen. Comp. Endocrinol., 49: 195-209 